\title{
Time Series Analysis of the Behaviour of Import and Export of Agricultural and Non-Agricultural Goods in West Africa: A Case Study of Nigeria
}

\author{
Olushina Olawale Awe ${ }^{1}$, Damola M. Akinlana ${ }^{2}$, OlaOluwa Simon Yaya ${ }^{2}$, Opeyemi Aromolaran \\ ${ }^{1}$ Department of Mathematical Sciences, Anchor University, Lagos, Nigeria \\ ${ }^{2}$ Department of Statistics, University of Ibadan, Ibadan, Nigeria \\ ${ }^{3}$ Department of Economics, Obafemi Awolowo University, Ile-Ife, Nigeria
}

\begin{abstract}
This study examines the time series properties of co-integration and causal relationship between oil (non-agricultural) and non-oil (agricultural) import and export in Africa's largest economy. We employed Granger causality and Johansen and Juselius's co-integration methods to investigate causal relationships among the variables Naira-US dollars exchange rate (USD), Naira-Pounds exchange rates (GBP), Oil Import (OI), Non-Oil import (NO), Oil Export (OE) and Non-Oil export (NE). We found empirical evidence for co-integration between oil and non-oil import. Our result reveals the existence of long run equilibrium between exchange rates, oil import and export, and non-oil import (agriculture) and export. Non-oil import and export involves those of agricultural products like Cocoa, Timber, Cassava and Groundnut. We show that there is bidirectional Granger causality from import and export of both agricultural (non-oil) and non-agricultural (oil) goods and vice-versa. This empirical relationship followed closely to what economic theory have suggested. The study recommends amongst others, that government should adopt appropriate monetary and fiscal policies that will ensure realistic and stable exchange rates and foster economic growth through import and export of agricultural products.
\end{abstract}

\section{Keywords}

Causality, import, export, Nigeria, exchange rate.

Awe, O. O., Akinlana, D. M., Yaya, O. S. and Aromolaran, O. (2018) "Time Series Analysis of the Behaviour of Import and Export of Agricultural and Non-Agricultural Goods in West Africa: A Case Study of Nigeria", AGRIS on-line Papers in Economics and Informatics, Vol. 10, No. 2, pp. 15-22. ISSN 1804-1930. DOI 10.7160/aol.2018.100202.

\section{Introduction}

The importance of import and export to a nation's economic growth and development cannot be overemphasized because they are necessary catalysts to the overall development of an economy. Over the years, the African continent, specifically, West African countries have been predominantly involved in the import and export of primary goods which are highly susceptible to the vagaries of unstable price movements in the world market. Some of the products that constitute the continent's export volume include crude oil, petroleum products, and agricultural products like Cocoa, Timber, Cashew, Cotton, among others. The implication of this is that, African continents' macroeconomic performance is highly correlated with the success of these products in the world market.
However, using Nigeria as a case study for the continent, Africa has experienced periods of instability in the barrel price of oil in the world market which, given the inelastic state of the products, resulted in low income for the economy with its indirect effect on employment, inflation rate, interest rate, and balance of payments. A prominent feature of Nigeria's export has remained basically the same since 1960. In the 1960s, and 1970s the Nigerian economy was dominated by agricultural commodity exports such as cocoa, groundnut, cotton and palm products. From the mid-1970s, crude oil became the main export product of the Nigerian economy. The export of crude oil now constitutes about $96 \%$ of total exports. According to Ayinde et.al.,2015, the performance of agriculture in Nigeria since 1970 clearly showed that it contributes more than 


\section{$40 \%$ of its annual Gross Domestic Product}

(GDP) and accounts for over $70 \%$ of the non-oil exports. The agricultural sector was the second largest export earner after crude oil and the largest employer of rural labor in Nigeria; therefore, it ranks as a key contributor to wealth creation, poverty reduction and food security in Nigeria.

Unfortunately, this position has fallen consistently to date due to, the appalling fluctuation in the nonoil export promotion, the world prices of agriculture and manufacturing products and the emergence of oil have helped in no small measure in diverging the role of agriculture in the nation's development. This situation is worsened by the almost total neglect of the agricultural sector; hence the performance of the non-oil exports in the past two decades leaves little or nothing to be desired. The major policy concern of the Nigerian government over the years has been to expand non-oil (which involves mainly agricultural products) export in a bid to diversify the nation's export base. Moreover, since the 2005 economic reform, the Nigerian government has continued to diversify its international trade market to include agricultural import and export.

Time series methodologies have been applied to analyze agricultural data in recent times (see for instance, Emokaro and Ayantoyinbo, 2014; Aloui, 2015; Hloušková et al., 2018; Kharin, 2018 and Ayinde et al., 2015). For instance, Syed et al. (2015) analysed the impact of agricultural exports on macroeconomic performance of Pakistan. Their Johansen co-integration technique result revealed that agricultural exports have a negative relationship with economic growth of Pakistan while non-agricultural exports have positive relation with economic growth. In a similar paper, Eke et al. (2015) applied co-integration test to examine exchange rate behaviour and trade balance in Nigeria. Their results also confirmed the presence of long-run relationship between trade balance and exchange rates; showing that the latter has a negative influence on trade balance in Nigeria. Uduakobong and Williams (2017) recently analyzed the relationship between exchange rate volatility and agricultural imports in Nigeria using annual data covering the period of 1970 to 2015. Their co-integration and Granger Causality test revealed the presence of a long run relationship between exchange rate volatility and agricultural import and that exchange rate does not Granger cause the movements in agricultural imports. However, time series studies on the behavior of exchange rates and agricultural (and non-agricultural) imports and exports in West African countries are non-extant.

The main objective of this study, therefore, is to examine the nature of causal relationship between the Nigerian exchange rate and agricultural and nonagricultural trade using time series methodologies. Studying the nature of the relationship between the Nigerian naira exchange rates and agricultural and non-agricultural trade is imperative in finding stability measure for the Nigerian currency which depicts economic growth, therefore, it is imperative to investigate the behaviour of the correlation and time series relationship between foreign trade (agricultural and non-agricultural) and foreign exchanges rates (USD and GBP) in Nigeria. The scope of this study examines the behavior of import and export of agricultural and nonagricultural goods using pre-recession (1960-2010) data on the Nigerian economy. The findings from this study would contribute to the existing evidences of co-integration and causality in the Nigerian foreign trade and exchange rates. Also, the results from this study would be useful for the policy makers and decision makers in the agriculture and economic sector.

\section{Materials and methods}

Annual time-series figures from 1960 to 2010 (pre-recession period) of naira-dollar exchange rate, naira-pounds exchange rate, imports (oil and non-oil), and exports (oil and non-oil) were used in this study. The data were obtained from the Central Bank of Nigeria Bulletin, 2010 edition, covering periods of 1960-2010. The unit of measurement for the import and export data is in USD Billions. The analytical techniques employed in this study for time series analysis include unit root test, Pearson correlation and Granger causality models.

Unit root test was conducted to test for the stationarity of the series while the Pearson's correlation coefficient and Granger causality test were used to examine the relationship between the six variables: Naira-US dollars exchange rate (USD), Naira-Pounds exchange rate (GBP), Oil Import (OI), Non-Oil import (NO), Oil Export (OE) and Non-Oil Export (NE). The methods and models used in this work were adapted from the works of Emakoro and Ayantoyinbo (2014), and Ayinde et al. (2015).

It is an established fact that most macroeconomic series appear to be non-stationary at their levels 
(Nelson and Plosser, 1982) and the use of such series in regression analyses lead to spurious regression estimates (Granger and Newbold, 1974). Thus, before examining integration relationships between or among financial variables, it is essential to test for unit root, and identify the order of stationarity. Test of the stationarity of financial series is paramount in other to avoid spurious results. There are several methods for testing the presence of unit roots; however, the most widely used method is the Augmented Dickey Fuller (ADF) test.

The ADF test corrects any serial correlation that might exist in the series by including lagged changes of the residual in the regression. It is defined as the regression of the first difference of the time series against the series lagged once of a constant and a time trend. It is expressed as;

$\Delta y_{t}=a_{0}+a_{1} y_{t-1}+\sum_{i=1}^{p} \varphi_{i} \Delta y_{t-i}+\varepsilon_{t}$

where $y_{t}$ represent each time series considered in this work; USD, GBP, OI, NO, OE and NE. $\Delta$ is the first difference operator, $\varepsilon_{t}$ is the error term with zero mean and constant variance, $\mathrm{a}_{0}, \mathrm{a}_{1}, \varphi(i=1, \ldots, p)$ are the parameters to be estimated and $\mathrm{i}$ is the included number of lag of each series. The non-rejection of the null hypothesis: $H_{0}: \mathrm{a}_{1}=0$ implies that, the series is nonstationary. Thus, differencing of the series is necessary to reach stationarity.

Next, the Pearson correlation was used to examine the strength of the relationships among the variables considered. That is, to observe the pairwiserelationships between foreign trades including agricultural and non-agricultural products (import and export) and exchange rates (naira-dollars and naira-pounds). Given the price of each series at time $t, X_{t}$ and $Y_{t}$ the degree of linear association between the variables were measured by the sign and magnitude of the correlation coefficient, $r$. The model is given as:

$r=\frac{\sum_{i=1}^{n}\left(\left(X_{i}-\bar{X}\right)\left(Y_{i}-\bar{Y}\right)\right)}{\sqrt{\sum_{i=1}^{n}\left(X_{i}-\bar{X}\right)^{2}} \sum_{i=1}^{n}\left(Y_{i}-\bar{Y}\right)^{2}}$

Where:

$r=$ Pearson correlation coefficient

$X_{i}$ and $Y_{i}=$ pairwise variables at time $t$

$\bar{X}$ and $\bar{Y}=$ mean of the variables.

After observing the inter-relationships between the variables considered in this work, it is needful for us to validate the linear combinations and co-integrations that exist between the variables.
Moreover, according to Granger (1988), causality tests are valid only in the presence of co-integration among the variables involved. Consequently, a necessary precondition to causality testing is to check the co-integration properties of the variables of interest. Engle and Granger (1987) pointed out that a linear combination of two or more non-stationary series may be stationary. If such a linear combination exists, the non-stationary (with a unit root), time series are said to be co-integrated. The stationary linear combination is called the co-integrating equation and may be interpreted as a long-run equilibrium relationship between the variables. This study further investigated whether or not the variables are co-integrated using Johansen and Juselius (1991) maximum likelihood method.

This test relies on two test statistics; the trace and maximum eigenvalue tests. The trace test statistics; $\quad \lambda_{\text {trace }}=T \sum_{i=r+1, n} \ln \left(1-\lambda_{i}\right)$ tests the null hypothesis that, there are at most $r$ number of co-integration against the alternative of no co-integrating vectors. In the equation above, $T$ represents the sample size and $\lambda$ represents the largest canonical correlation under trace. The maximum eigenvalue test uses the relationship; $\lambda_{\max }=-T \ln \left(1-\lambda_{r+1}\right)$ with the null hypothesis same as that of trace value above against the alternative hypothesis of $r+1$.

Finally, the Granger causality test was employed to further examine the relationships between the variables. That is, to provide additional evidence as to whether and in which direction cost of foreign trade influence exchange rates and vice-versa. The Granger causality analysis was proposed by Granger (1969) to examine the causal relationship between variables. This concept introduced by Granger, has turned out to be extremely important to economist and financial analyst in testing plausible economic relationships between non-stationary economic time series. It uses a one-sided distributive lag whereby the incremental forecasting value of past and present history of one variable on another variable is used as the yard stick. Consequently, it stated that, " $Y_{t}$ is causing $X_{t}$ if the former is better able to predict the latter using all available information". In Granger (1969)'s bi-variate framework, variable $X$ is said to cause $Y$ if the past and current values of $X$ facilitates the forecasting of $Y$ when employed in conjunction with the past value of $Y$ as compared with when only past values of $Y$ are employed. 


\section{Results and discussion}

The study uses figures (graphs) and tables to present the results for easy understanding. Figure 1 is the graph of each series (import and export) before any stationarity test was performed on them. It clearly shows the nonstationarity properties of the series. The lowest and highest prices of each variable were observed for the duration of the data. Considering the trend of these data, we observed from Figure 1 that all the series increased sharply in the mid-1990 except non-oil (agricultural) export which started increasing in early 2000, probably during the democratic regime of 2003 . We also noticed that there was a sharp drop in the value of non-oil (agricultural) import around the year 2007 during the end of another democratic regime in Nigeria, while the change in cost of non-oil export was negligible from 1960-1995.

Table 1 shows the minimum, maximum, mean and standard deviation of the six variables. The study shows that, oil export has the highest
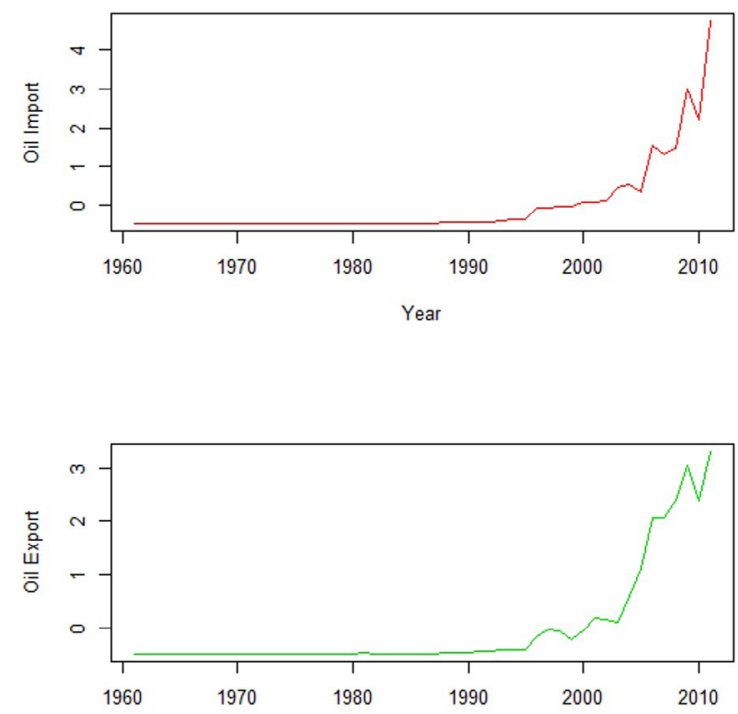

Source: Author's processing

Figure 1: Time series trend of agricultural and non-agricultural import/export.

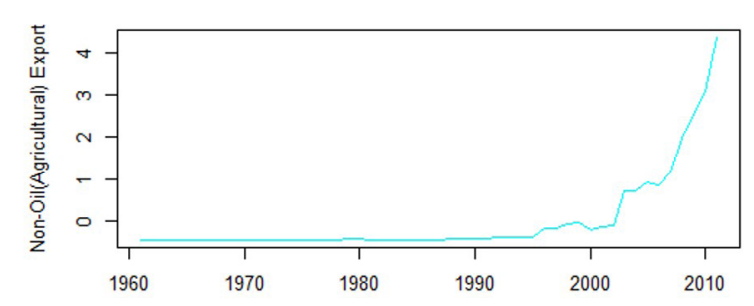
presented previously, it is expedient that all variables in this study are tested for stationarity using Augmented Dickey-Fuller (ADF) test. The ADF test reveals that the exchange rate variables are non-stationary and integrated of order 1, while the remaining variables are integrated of order two 2 (see Table 2). This is an indication of co-integration between the variables considered.

Next, the Johansen and Juselius (1991) testing procedure was applied on the differenced series

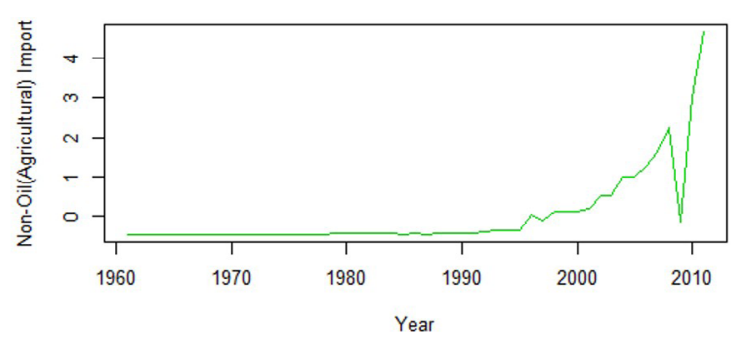

\begin{tabular}{|l|c|c|c|c|}
\hline Variables & Minimum & Maximum & Mean & Std Deviation \\
\hline USD & 0.5464 & 148.455 & 34.3192 & 52.4815 \\
\hline GBP & 1.077 & 249.993 & 57.91 & 89.3748 \\
\hline OI & 22 & 2073579 & 183155.3 & 400706.7363 \\
\hline NO & 346 & 5931795 & 547506 & 1154799.581 \\
\hline OE & 9 & 10639417 & 1379064 & 2803497.872 \\
\hline NE & 203.2 & 396377.2 & 37216.2 & 81985.82829 \\
\hline
\end{tabular}

Source: Author's computation

Table 1: Descriptive statistics of the variables. 


\begin{tabular}{|l|l|l|c|c|c|c|}
\hline \multirow{2}{*}{ Variables } & \multicolumn{1}{|c|}{ Form } & \multirow{2}{*}{ P-value } & \multirow{2}{*}{ ADF test } & Critical-Value & & \multirow{2}{*}{ Lag order } \\
\cline { 5 - 6 } & & & & $\mathbf{1 \%}$ & $\mathbf{5 \%}$ & \\
\hline US Dollar & Level & 0.9959 & 0.9869 & -3.5683 & -2.9212 & 10 \\
\hline & First Difference & 0.0203 & -3.3007 & -3.5744 & -2.9238 & 10 \\
\hline & Second Difference & 0.0006 & -4.6083 & -3.6105 & -2.9389 & 10 \\
\hline & Level & 1 & 2.4356 & -3.6056 & -2.9369 & 10 \\
\hline & First Difference & 0.0066 & -3.7304 & -3.5744 & -2.9238 & 10 \\
\hline & Second Difference & 0.0001 & -5.3015 & -3.5847 & -2.9281 & 3 \\
\hline & Level & 1 & 3.6923 & -3.5885 & -2.9297 & 6 \\
\hline & First Difference & 1 & 3.6381 & -3.5811 & -2.9266 & 3 \\
\hline & Second Difference & 0.0482 & -2.9442 & -3.5847 & -2.9281 & 3 \\
\hline Non-Oil Import & Level & 0.9977 & 1.2019 & -3.5885 & -2.9297 & 6 \\
\hline & First Difference & 0.6614 & -1.2121 & -3.5811 & -2.9266 & 3 \\
\hline & Second Difference & 0 & -5.6242 & -3.5847 & -2.9281 & 3 \\
\hline Oil Export (OE) & Level & 0.9999 & 2.3037 & -3.6055 & -2.9369 & 10 \\
\hline & First Difference & 1 & 5.8796 & -3.6105 & -2.9389 & 10 \\
\hline & Second Difference & 0 & -6.7108 & -3.5847 & -2.9281 & 3 \\
\hline Non-Oil Export & Level & 1 & 5.3183 & -3.5885 & -2.9297 & 3 \\
\hline & First Difference & 1 & 6.7055 & -3.6056 & -2.9369 & 6 \\
\hline & Second Difference & 0.0018 & -4.1978 & -3.5847 & -2.9281 & 3 \\
\hline
\end{tabular}

Source: Author's computation

Table 2: Unit root test on the variables.

to test whether they are co-integrated or not. The co-integration test reported in Table 3 shows the presence of five co-integrating vectors in the model. The implication of this result is that, variables considered share the same stochastic trend. That is, there is a long-run relationship between them (Enders and Lee, 2004).

Furthermore, the correlations between the six variables considered in this work were estimated and reported in Table 4 to determine the level of the linear relationships. The Pearson correlation coefficients among the variables signal positive correlation between the variables. It suggests co-movements between the variables. All the bi-variate correlations computed between oil and non-oil import and export and exchange rates (USD and GBP) reveal that there was no correlation coefficients lower than 0.5 . The high correlations of the variables pairs are consistent with the high degree of integration between import, export and naira exchange rate; showing that a shock in each variable may have an influence on any of the variables considered in this study. For instance, a shock in non-oil export will have an impact on oil import.

Lastly, the Granger causality test was carried out in order to assert the statement that, any two co-integrated variables have either unidirectional or bi-directional causality between them (Awe, 2012, Awe et al., 2016). The decision rule for this test states that, if the coefficients of both cases in a pair are not significant, there is no causality between them, otherwise, there is bi-directional causality between them. However, if one of the coefficients is significant and the other is not, then the former Granger-causes the later and it is termed unidirectional. The pairwise comparison tests results on all the pairs of variables are presented in Table 4. These results confirm that, any two co-integrated variables have either unidirectional or bi-directional causality between them.

The results in Table 5 suggest that, in the fifteen linear combination, the direction of causality is unidirectional in 6 cases, bidirectional in 4 cases and absence of causality in the remaining 5 cases. Specifically, there is no causality between the following pairs of variables: OI and USD, NO and USD, NE and USD, NO and GBP and NE and GBP. This finding supports the evidence found in Uduakobong and Williams (2017). More so, the study reveals that; naira-US dollars (USD) Granger-causes naira-pounds and oil export while naira-pounds (GBP) grangercause oil import and oil export. Moreover, according to international trade policies, when price of an export rises, it produces a demand, thereby 


\begin{tabular}{|l|l|l|l|l|l|l|}
\hline & \multicolumn{3}{|c|}{$\lambda_{\text {trace }}$} & \multicolumn{3}{c|}{$\lambda_{\max }$} \\
\hline No of CE & Test stat. & C.values & p-values & Test stat. & C.values & p-values \\
\hline$r=0$ & 732.0864 & 95.7537 & 0.0001 & 278.4324 & 40.0776 & 0.0001 \\
\hline$r \leq 1$ & 453.654 & 69.8188 & 0.0001 & 199.9524 & 33.8769 & 0.0001 \\
\hline$r \leq 2$ & 253.7016 & 47.85613 & 0.0001 & 141.916 & 27.5843 & 0 \\
\hline$r \leq 3$ & 111.7856 & 29.79707 & 0 & 92.08442 & 21.1316 & 0 \\
\hline$r \leq 4$ & 19.70119 & 15.49471 & 0.0109 & 19.16648 & 14.2646 & 0.0077 \\
\hline$r \leq 5$ & 0.534701 & 3.841466 & 0.4646 & 0.534701 & 3.8415 & 0.4646 \\
\hline
\end{tabular}

Source: Author's computation

Table 3: Johansen-Juselius co-integration test results.

\begin{tabular}{|l|l|l|l|l|l|l|}
\hline Variables & USD & GBP & OI & NO & OE & NE \\
\hline USD & 1 & 0.9931 & 0.7909 & 0.8098 & 0.8444 & 0.8004 \\
\hline GBP & 0.9931 & 1 & 0.7842 & 0.7997 & 0.8622 & 0.8007 \\
\hline OI & 0.7909 & 0.7842 & 1 & 0.8782 & 0.9538 & 0.9748 \\
\hline NO & 0.8098 & 0.7997 & 0.8782 & 1 & 0.8598 & 0.913 \\
\hline OE & 0.8444 & 0.8622 & 0.9538 & 0.8598 & 1 & 0.9442 \\
\hline NE & 0.8004 & 0.8007 & 0.9748 & 0.913 & 0.9442 & 1 \\
\hline
\end{tabular}

Source: Author's computation

Table 4: Pearson correlation coefficints results.

\begin{tabular}{|c|c|c|c|c|c|}
\hline Pairs & Pairs $\left(\mathrm{H}_{0}\right)$ & F-stat & P-value & Decision & Types of Causality \\
\hline \multirow{2}{*}{1} & GBP to USD & 2.1699 & 0.1262 & $\mathrm{DNR} \mathrm{H}_{\mathrm{o}}$ & \multirow{2}{*}{ Unidirectional } \\
\hline & USD to GBP & 8.4845 & $0.0008 *$ & Reject $\mathrm{H}_{\mathrm{o}}$ & \\
\hline \multirow{2}{*}{2} & OI to USD & 1.2135 & 0.3069 & $\mathrm{DNR} \mathrm{H}_{\mathrm{o}}$ & \multirow{2}{*}{ No Causality } \\
\hline & USD to OI & 0.7597 & 0.4738 & $\mathrm{DNR} \mathrm{H}_{\mathrm{o}}$ & \\
\hline \multirow{2}{*}{3} & NO to USD & 1.0091 & 0.3728 & $\mathrm{DNR} \mathrm{H}_{\mathrm{o}}$ & \multirow{2}{*}{ No Causality } \\
\hline & USD to NO & 3.0092 & 0.0596 & $\mathrm{DNR} \mathrm{H}_{\mathrm{o}}$ & \\
\hline \multirow{2}{*}{4} & OE to USD & 0.0277 & 0.9727 & $\mathrm{DNR} \mathrm{H}_{0}$ & \multirow{2}{*}{ Unidirectional } \\
\hline & USD to $\mathrm{OE}$ & 12.4798 & 5.E- $05^{*}$ & Reject $\mathrm{H}_{\mathrm{o}}$ & \\
\hline \multirow{2}{*}{5} & NE to USD & 0.0436 & 0.9573 & $\mathrm{DNR} \mathrm{H}_{0}$ & \multirow{2}{*}{ No Causality } \\
\hline & USD to NE & 0.6330 & 0.5357 & $\mathrm{DNR} \mathrm{H}_{\mathrm{o}}$ & \\
\hline \multirow{2}{*}{6} & OI to GBP & 1.5871 & 0.216 & $\mathrm{DNR} \mathrm{H}_{\mathrm{o}}$ & \multirow{2}{*}{ Unidirectional } \\
\hline & GBP to OI & 4.5554 & $0.0159 *$ & Reject $\mathrm{H}_{\mathrm{o}}$ & \\
\hline \multirow{2}{*}{7} & NO to GBP & 1.2519 & 0.2959 & $\mathrm{DNR} \mathrm{H}_{\mathrm{o}}$ & \multirow{2}{*}{ No causality } \\
\hline & GBP to NO & 2.0901 & 0.1358 & $\mathrm{DNR} \mathrm{H}_{\mathrm{o}}$ & \\
\hline \multirow{2}{*}{8} & OE to GBP & 1.8949 & 0.1624 & $\mathrm{DNR} \mathrm{H}_{\mathrm{o}}$ & \multirow{2}{*}{ Unidirectional } \\
\hline & GBP to $\mathrm{OE}$ & 15.1594 & 1.E- $05^{*}$ & Reject $\mathrm{H}_{\mathrm{o}}$ & \\
\hline \multirow{2}{*}{9} & NE to GBP & 1.0262 & 0.3668 & $\mathrm{DNR} \mathrm{H}_{\mathrm{o}}$ & \multirow{2}{*}{ No Causality } \\
\hline & GBP to NE & 0.7507 & 0.478 & $\mathrm{DNR} \mathrm{H}_{\mathrm{o}}$ & \\
\hline \multirow{2}{*}{10} & $\mathrm{NO}$ to $\mathrm{OI}$ & 7.4791 & $0.0016^{*}$ & Reject $\mathrm{H}_{\mathrm{o}}$ & \multirow{2}{*}{ Bidirectional } \\
\hline & OI to $\mathrm{NO}$ & 50.7303 & 4.E-12* & Reject $\mathrm{H}_{\mathrm{o}}$ & \\
\hline \multirow{2}{*}{11} & $\mathrm{OE}$ to $\mathrm{OI}$ & 2.7699 & 0.0736 & $\mathrm{DNR} \mathrm{H}_{\mathrm{o}}$ & \multirow{2}{*}{ Unidirectional } \\
\hline & $\mathrm{OI}$ to $\mathrm{OE}$ & 34.7268 & 9.E-10* & Reject $\mathrm{H}_{\mathrm{o}}$ & \\
\hline \multirow{2}{*}{12} & $\mathrm{NE}$ to $\mathrm{OI}$ & 10.9912 & $0.0001 *$ & Reject $\mathrm{H}_{\mathrm{o}}$ & \multirow{2}{*}{ Bidirectional } \\
\hline & OI to $\mathrm{NE}$ & 19.0855 & 1.E-06* & Reject $\mathrm{H}_{\mathrm{o}}$ & \\
\hline
\end{tabular}

Source: Author's computation

Table 5: Pair-wise Granger causality test results (to be continued). 


\begin{tabular}{|c|c|c|c|c|c|}
\hline Pairs & Pairs $\left(\mathbf{H}_{\mathbf{o}}\right)$ & F-stat & P-value & Decision & Types of Causality \\
\hline \multirow{2}{*}{13} & OE to NO & 17.2806 & $3 . \mathrm{E}-06^{*}$ & Reject $\mathrm{H}_{\mathrm{o}}$ & \multirow{2}{*}{ Bidirectional } \\
\cline { 2 - 5 } & NO to OE & 47.4544 & $1 . \mathrm{E}-11^{*}$ & Reject $\mathrm{H}_{\mathrm{o}}$ & \\
\hline \multirow{2}{*}{14} & $\mathrm{NE}$ to NO & 31.3377 & $3 . \mathrm{E}-09^{*}$ & Reject $\mathrm{H}_{\mathrm{o}}$ & \multirow{2}{*}{ Unidirectional } \\
\cline { 2 - 5 } & $\mathrm{NO}$ to NE & 5.9267 & 0.0053 & ${\text { DNR } \mathrm{H}_{\mathrm{o}}}_{n}$ & \\
\hline \multirow{2}{*}{15} & $\mathrm{NE}$ to OE & 3.4364 & $0.0410^{*}$ & Reject $\mathrm{H}_{\mathrm{o}}$ & \multirow{2}{*}{ Bidirectional } \\
\cline { 2 - 5 } & OE to NE & 23.4456 & $1 . \mathrm{E}-07^{*}$ & Reject $\mathrm{H}_{\mathrm{o}}$ & \\
\hline
\end{tabular}

Source: Author's computation

Table 5: Pair-wise Granger causality test results (continuation).

driving up the value of a nation's currency. From this study, we also note that unidirectional causality runs from oil import to oil export and non-oil export to non-oil import. Furthermore, bi-directional causality was found in oil import and non-oil import, non-oil (agricultural) export and oil import; oil export and non-oil import; and non-oil export and oil export.

\section{Conclusion}

This paper has examined the co-integration and causal relationship of import and export of agricultural and non-agricultural goods in Nigeria. The Pearson correlation coefficient result shows that agricultural and non-agricultural trade and the Nigerian exchange rates variables were positively linearly correlated. These results are significant because the co-integration test results reveal the presence of a long-run relationship between the Nigerian exchange rates and agricultural and non-agricultural import.

The time series method of Granger causality test on the six variables revealed that, the naira-dollar and naira-pounds do not influence the movement in non-oil (agricultural) import. More so, the test shows the presence of bi-directional causality between foreign trades in Nigeria. That is, it confirms the inter-relationship that exist between agricultural and non-agricultural import and export in Nigeria. This study has also revealed the critical role that exchange rate plays in a country's economy given its long run relationship with agricultural and non-agricultural imports and exports. Evidence from this study revealed that agricultural trade, just like non-agricultural trade also influenced Nigerian exchange rates movement.

We therefore recommend that, the reform agenda of governments in West African countries should be systematic and sustainable such that government strategies can be channeled to improve the competitiveness of their agricultural products in the international market. Also, policy makers in Nigeria should take bold steps to improve productivity in agriculture on a larger scale so that non-oil (agricultural) export can considerably compete with oil export in the economy in order to forestall recurring recessions.

Corresponding authors:

Dr. Olushina Olawale Awe

Department of Mathematical Sciences, Anchor University

Lagos State, Nigeria

E-mail:oawe@aul.edu.ng

\section{References}

[1] Alaoui, A. E. (2015) "Causality and Cointegration Between Export, Import and Economic Growth: Evidence from Morocco", Journal of World Economic Research, Vol. 4, No. 3. pp. 83-91. E-ISSN 2328-7748, 2328-773X. DOI 10.11648/j.jwer.20150403.14.

[2] Awe, O. O. (2012) "On Pairwise Granger Causality Modelling and Econometric Analysis of Selected Economic Indicators", Interstat Jounal (U.S.A), Vol.17, No. 5., pp. 1-16.

[3] Awe, O. O., Akinlana, D. M. and Adesunkanmi, S. O. (2016) "Foreign Trade-Foreign Exchange Nexus in Nigeria: A Vector Error Correction Modelling Approach", Binus Business Review, Vol. 7., No.1, pp. 1-7. ISSN 2476-9050. DOI 10.21512/bbr.v7i1.1427. 
[4] Ayinde, O. E., Ilori, T. E., Ayinde, K. and Babatunde, R. O., (2015) "Analysis of the behaviour of prices of major staple foods in West Africa: A case study of Nigeria", Agris on-line Papers in Economics and Informatics, Vol. 7, No. 4, pp. 3-17. ISSN 1804-1930.

[5] CBN (2010) "Central Bank of Nigeria Statistical bulletin". [Online]. Available: http://cenbank.org/ [Accessed: 15 Aug. 2017].

[6] Dickey, D. A. and Fuller, W. A. (1979) "Distribution of the Estimators for Autoregressive Time Series with a Unit Root", Journal of the American Statistical Association, Vol. 74., No. 366, pp. 427-431. E-ISSN 1537-274X, ISSN 0162-1459. DOI 10.2307/2286348.

[7] Eke, I. C., Eke, F. A. and Obafemi, N. O., (2015) "Exchange Rate Behaviour and Trade Balances in Nigeria: An empirical investigation", International Journal of Humanities and Social Science, Vol. 5 No.8(1), pp. 71-78. E-ISSN 2221-0989, ISSN 2220-8488.

[8] Emokaro, C. O. and Ayantoyinbo, A. A. (2014) "Analysis of Market Integration and Price Variation in Rice Marketing in Osun State, Nigeria", American Journal of Experimental Agriculture, Vol. 4, No. 5. DOI 10.9734/AJEA/2014/7639.

[9] Engle, R. F., and Granger, C. W. J. (1987) "Co-integration and Error-Correction Representation, Estimation and Testing", Econometrica, Vol. 55, pp. 251-276. E-ISSN 1468-0262. DOI $10.2307 / 1913236$.

[10] Granger, C. and Newbold, P. (1974) "Spurious Regression in Econometrics", Journal of Econometrics, Vol. 2, No. 2, pp. 111-120. ISSN 0304-4076. DOI 10.1016/0304-4076(74)90034-7.

[11] Granger, C. W. J. (1969) "Investigating Causal Relations by Econometric Models and Cross Spectral Methods", Econometrica, Vol. 37. pp. 424-35. E-ISSN 1468-0262. DOI 10.2307/1912791.

[12] Granger, C. W. J. (1988) "Testing for causality-A personal viewpoint", Journal of Economic Dynamic and Control, Vol. 2., No. 4, pp. 329-352. ISSN 0165-1889. DOI 10.1016/0165-1889(80)90069-X.

[13] Hloušková, Z., Ženíšková, P. and Prášilová, M. (2018) "Comparison of Agricultural Costs Prediction Approaches", AGRIS on-line Papers in Economics and Informatics, Vol. 10, No. 1, pp. 3-13. ISSN 1804-1930. DOI 10.7160/aol.2018.100101.

[14] Johansen, S. and Juselius, K. (1991) "Maximum Likelihood Estimation and Inference on Cointegration With Applications to the Demand for Money", Oxford Bulletin of Economics and Statistics, Vol.52. No.2, pp. 169-210. ISSN 0305-9049. DOI 10.1111/j.1468-0084.1990.mp52002003.x.

[15] Kharin, S. (2018) "Price Transmission Analysis: The case of milk products in Russia", AGRIS on-line Papers in Economics and Informatics, Vol. 10, No. 1, pp. 15-23. ISSN 1804-1930. DOI 10.7160/aol.2018.100102.

[16] Nelson, C. R and Plosser, C. I. (1982) "Trends and Random Walks in Macroeconomic Time Series: Some evidence and implications", Journal of Monetary Economics, Vol. 10, No.2, pp. 139-162. ISSN 0304-3932. DOI 10.1016/0304-3932(82)90012-5.

[17] Syed, W. S., Muhammed, A. and Rana, M. A. (2015) "Agricultural export and economic growth: A case study of Pakistan", MPRA, Vol. 5, No. 8. ISSN 2225-0972.

[18] Uduakobong, S. I. and Williams, A. O. (2017) "Exchange Rate Volatility and Non-Oil Imports in Nigeria: A Cointegration Analysis", Advances in Social Sciences Research Journal, Vol. 4, No. 16, pp. 165-176. ISSN 2055-0286. DOI 10.14738/assrj.416.3508. 